\title{
Ceren Özpınar, Periods in the Art History of Turkey
}

\section{Translated by Ayșe Lucie Batur}

First published in Turkish as "Türkiye Sanat Tarihinde Dönemler," Edebiyat Fakültesi Dergisi

33, no 1 (2016): 125-140.

\begin{abstract}
Western art history draws on periodization as a method for organizing knowledge about the art of the past. This article examines the use of periodization in Turkey between 1970 and 2010, focusing on a select number of Turkish-language narratives, published in books, journals, and exhibition catalogs. The artistic periods of Modern and Contemporary art, which are common in traditional Eurocentric art history, are also present in Turkish art history but followed by an additional period, which can be translated as Current. The use of shorter artistic periods in Turkish art history also presents differences to Western conventions, as the short periods can refer to a specific type of art as well as a period. This article examines different narratives, identifying novelties, changes, and repetitions in Turkish art historiography over a period of forty years. It discusses how Turkish art history challenges established models of modern art history. It aims to reveal the diverse temporal and original arrangements of the past, many of which are found in vernacular narratives and confront global dominant art histories.
\end{abstract}

KEYWORDS: Turkish art history, historiography of art, periodization, canon of art, Modern art, Contemporary art, Current art.

\section{Introduction by Wendy Shaw (Freie Universität Berlin)}

Educated in both Turkey and Britain, Ceren Özpınar is sensible to the discursive distinctions between English language and Turkish art-historical periodization. The article reflects a critical view of the possibilities of cross-cultural periodization, and thereby interpretation, of global contemporary art. With few voices to analyze the dynamics of non-Western art critical practices, this article provides a much-needed corrective to the faith that words mean the same thing when 
used in different contexts. It provides excellent insight into important trends in contemporary arts discourses in Turkey.

Art is often called a "universal language." Yet we all recognize that the possibilities of communication that it embodies depend on the access of creators to recognizable creative discourses, and the access of interpreters to recognizable interpretive ones. These discourses are not always simultaneous in all contexts. This article addresses such cross-cultural discontinuity by focusing on the periodization of contemporary art in Turkey. Whereas in English, there is an already fuzzy distinction between "modern" and "contemporary" art, in Turkish this distinction becomes three-fold: modern, contemporary (çağdaş, meaning literally "of the same age”), and current (güncel, meaning literally "of the day"). Even when these terms seem to correspond to familiar periodizations, they often represent different temporalities and associated practices. Focusing on the issue of periodization in art criticism, this article sorts out the complexities associated with grouping art through terminologies that seem to focus on time through periodization, but generally imply associated styles and intellectual movements. In the growing field of global modern and contemporary art, such discourse is sorely lacking. Investigating the work of outstanding individual artists or groups, developing Euro-American interest in non-Euro-American modern arts rarely considers the discursive contexts of their production, dissemination, or incorporation into local historical narratives. In emphasizing such critical discourse, this article not only provides insight into the discursive realm of Turkish art criticism, it also underscores the need to recognize artistic practices within the cultural spheres of its emergence and discursive historicization. Through this contextualization, it enables greater insight into the social functions of art in a relationship with global arts practices. It will thus be of interest to art historians interested in non-Western modern and contemporary art, particularly of the Middle East and Turkey. 


\section{Periods in the Art History of Turkey*}

\section{By Ceren Özpinar}

\section{Introduction}

Periodization is used as a method to organize time in historical narratives, to facilitate the study of the institutionalized system of history by dividing it into periods, and to make it easier to conceive time. Transformations, events, and theories that are considered highly significant for explaining historical process are represented through periods. ${ }^{1}$ Periods also propose a universal system or an ideal concept for specific timelines that are encountered in historical narratives. This proposition supports the linear, progressive, and diachronic conception of historical time. ${ }^{2}$ Periods within the linear flow of time also reveal continuities in history as well as the dissociations that enable the formation of new continuities. One can make a periodization that spans over a whole century under a single point of view, or, when that point of view proves insufficient, create a narrative order to study transformations throughout decades. ${ }^{3}$ This is why periods can be short or long within certain time intervals, depending on different paces of time. Accordingly, a period can be called large period, mega-period, or short period. As in historiography, the periodization method used in art historiography allows for establishing art-historical knowledge in various temporalities and contexts.

\section{Method}

This article analyzes the historical narratives of the visual arts in Turkey, published between 1970 and 2010 in art magazines, edited volumes on art, catalogs of exhibitions or collections in the Turkish language in Istanbul, Ankara, and Izmir. Art-historical narratives are taken as descriptive texts that organize events chronologically, focus on a single story with an internal unity, create a 
structure based on persons/events/institutions rather than on abstract concepts, and start from specific events rather than what is general or statistical.

\section{Large Periods: Modern, Contemporary, Current}

Periodization is a basic method used to organize the temporal intervals in art histories that pertain to various geographical regions, which is commonly used in art historiography in Turkey. As one of the foundation stones of modern historiography, periodization helped the linear and progressive perspective in historiography to prevail in art historiography. Long periods, such as Renaissance, Modern, or Contemporary, that are often found in the historiography of art, largely facilitated the writing and transmission of art history. In addition, the impact of modern historiography on the art histories from a range of geographical regions led to the universal acceptance of these or similar large periods. Even though this acceptance has provided a method and perspective for the art histories of non-Western regions, it has also led to the diffusion of a Eurocentric perspective along with it. The outcomes of this diffusion have been the conception of Europe as a reference point in non-Western art histories, and the creation of Western histories that neglect other cultures. Hence, the periodization under the title Modern has, for instance, been criticized by art historians for ignoring women, minorities, and non-Western artists. ${ }^{4}$

Art historians have conducted studies in order to eradicate the inequalities that these periodizations engender in historical consciousness. Erwin Panofsky suggested joining together large periods, such as Baroque, Modern, and Postmodern under a mega-period called Post-Renaissance. This would enable both bringing out the largest units in Western art and establishing connections with the arts of non-Western regions. ${ }^{5}$ Wilhelm Pinder approached art history under two mega-periods called Contemporaries and Near-Contemporaries. Pierre Daix, on the other hand, studied historical time in smaller temporal intervals and revealed subjective formations. In his monograph on Picasso (1966), Daix analyzed the artist's works from 1900 to 1906 in short periods spanning a few months. There 
are, however, also studies that argue for periods formed under a single concept in order to highlight singularities, differences, heterogeneities, inconsistencies, discontinuities, and conflicts. ${ }^{6}$ Although Chinese art history had periodized artistic practice idiosyncratically according to temporal intervals based on dynasties since the ninth century, ${ }^{7}$ it incorporated the periods of modern art history into its historiography as a result of their contact with the West in the nineteenth century. Accordingly, the period from 1839 to 1976, the year of the death of Mao Zedong (1893-1976), is called Modern, and the period after 1976 is called Contemporary. ${ }^{8}$

Art practices based in Europe and North America in the nineteenth and twentieth centuries have often been studied under large periods, such as Modern, After-Modern, Contemporary, and Postmodern in historical narratives. Under the large period called Modern, there are smaller periods that are based on style, artist groups, or art movements (such as Abstract, Die Brücke, etc.). The periodization of After-Modern, Contemporary, and Postmodern is established through style, artist groups, or movements, as in the case of the Modern, as well as within the framework of individual artists, concepts, or the material. In art historiography in Turkey, Modern, Contemporary, and Current emerged as large periods.

\section{Modern}

In modern art historiography, Modern emerges as a concept that breaks from the traditional, academic, and popular art forms by signaling art for art's sake's motto of high art. At the same time, Modern constitutes one of the characteristic features of European culture. ${ }^{9}$ Modernity and modernization in Turkey were developed as a complete project during the Republican Period and served to naturalize and internalize of all cultural dimensions that supposedly made Europe modern. ${ }^{10}$ In Turkey, modernization has been defined in relation to Westernization, which led the Modern period to cover a wide temporal span in art historiography. At the same time, since Modern was conceived in connection with European-based Modernism, artists who practice within the movements considered as Modern in modern Turkish art historiography, for instance those falling 
within Turkish Impressionism or Cubism, are treated under the title of Modern. Hence, as a concept, Modern came to mean "perspectival depictions of spatial relationship on a flat surface" in the Ottoman era that formed "the prelude to Turkish modernity in art"11 or "a direction that tries to fulfill the requirements of being Western." ${ }^{12}$ [insert figure 1 and 2 near here]

In terms of temporal organization, the artistic practices not only of the early twentieth century but also from 1950 to 2000 are called Modern in the art-historical narrative, as in the exhibition Modern Turk: Turkish Art in the Second Half of the $20^{\text {th }}$ Century that was organized in 2001. ${ }^{13}$ Yet, the exhibition Modern Turk II, which was organized in 2007, presents the period between 1950 and 1970 as Modern. ${ }^{14}$ In a similar way, in the art-historical narratives authored for the exhibition Modern and Beyond held in the same year, the period between 1950 and 1990 are described as both Modern period and "modernization." 15 In the narratives that accompanied this exhibition, the "threshold of modernism" and the "transformation in 'Turkish modern art"" mark the 1950s or right after the Second World War. ${ }^{16}$

In short, there are diverging views on the extent, the beginning, and the end of the Modern in the art histories in Turkey. Besides marking a period, Modern in these art-historical narratives also signifies the material or the style of artworks. Modern art histories of Western Europe and North America also present debates on the periodization and the founders of the Modern, Contemporary, and Postmodern. There are differing views as to who started the Modern period / Modernism. It could be Jacques-Louis David (1748-1825), Manet (1832-1883), Cézanne (18391906), or Cubism depending on the narrative. ${ }^{17}$ Furthermore, there is no consensus in art histories regarding the beginning or end dates, or the description of the period following the Modern, that is After-Modern or Postmodern. Postmodern is, as a period, full of problematizations that started in the 1990s and in which the Western art tradition has split into many traditions, according to the books Art History (1995) ${ }^{18}$ and Gardner's Art Through the Ages (2004). ${ }^{19}$ It is a period with no prevailing style, material, or movement according to History of Modern Art (2003). ${ }^{20}$ 
Nevertheless, Postmodern is defined as a period diverging from the narrative organization of the Modern and from meta-narratives, with no stylistic unity. ${ }^{21}$ Even though the term is described as a revolt against the established forms of High Modernism, it is observed that the term does not define a certain aesthetic or style. ${ }^{22}$ The difference between Postmodern and Contemporary is also a topic of discussion. Some narratives claim that Postmodern starts with Pop Art in the 1960s and Andy Warhol (1928-1987), or with Pop Art and the collages of Robert Rauschenberg (19252008). ${ }^{23}$ Similar to Postmodern, Contemporary is defined as artistic practices emerging after the Modern. ${ }^{24}$ Dated at the end of the 1980 s, Contemporary parallels with "contemporary hegemonic formations" that are linked to Postmodernity as well as with Globalism and Neoliberalism. ${ }^{25}$

\section{Contemporary}

Each art-historical narrative in Turkey dates the periods of Postmodern, After-Modern, and Contemporary differently. Some narratives state that following on from the Modern, a period called After-Modern started in the mid 1980s $;^{26}$ that while the 1960 s and 1970 s witnessed a "transformation," "[i]n the 1980s ... art shook off its old modernist dust in the wake of the transition from state capitalism to liberal economy;"27 that there was a "break" or a "watershed" from Modernism to Postmodernism at the end of the 1970 s and $1980 \mathrm{~s} ;{ }^{28}$ or that "a turning point of progress" marked the second half of the 1980s and the 1990s introduced new materials to art. ${ }^{29}$ This "break" is conceived as a "rupture" or a "paradigm shift" and is situated in the 1990s. ${ }^{30}$ Phenomena such as a break or a rupture, which create a discontinuity in the historical narrative by diverging from periods, can be read as a powerful statement that suspends the accumulation and development of knowledge, and forces it to enter into a new historical time by breaking it off from its origin and motivation. $^{31}$

Postmodern and Contemporary are often used in place of one another in narratives. Accordingly, certain features that are indeed attributed to Postmodernism, such as providing a critique of Modernism, having an eclectic structure, being multilayered, creating a kitsch and excessive 
visuality, devaluing 'meta-narratives,' and relating to subjects such as Deconstruction, Orientalism, the Other, différance, and de-territorialization are conceived as concepts and theories that also constitute the Contemporary. ${ }^{32}$ Even though there is no consensus on its date, the Modern ends when the period called Contemporary starts in the art history of Turkey. There are also differing views on the historical extent and definition of the Contemporary.

Contemporary is also one of the concepts that are considered together with the project of modernity. The nation-state ideology has rendered modernization synonymous with contemporaneity. That is why before becoming the name of a period in art history, in the narratives of the 1970s, the word Contemporary [çăgdaş] was regarded as a cultural quality or a teleological progress, which both represented the modernization project and refers to the art of the era. ${ }^{33}$ Vasif Kortun states that it was the art critic and politician Bülent Ecevit who used contemporary art in this sense for the first time in his writings on art in the $1950 \mathrm{~s} .{ }^{34}$ An example of the use of the word Contemporary in its double meaning is Nurullah Berk's naming of eleven artists who produced art from the Republican Period to the 1970s as "the representatives of Contemporary Art" in his article series in the journal Sanat Dünyamız (1976-1980). An example of the use of the word Contemporary both in terms of a time period and in relation to Republican and "Westernization" ideologies is Semra Germaner's naming of painting from the proclamation of the Republic to 1999 as Contemporary Art. $^{35}$

In the art-historical narratives in Turkey, the early attempts or the emergence of the Contemporary as a period is dated to the $1960 \mathrm{~s} ;{ }^{36}$ its "turning point" is placed at $1967 ;{ }^{37}$ its first manifestations at the $1980 \mathrm{~s}$ or the end of $1980 \mathrm{~s} ;{ }^{38}$ its beginnings at the $1990 \mathrm{~s} .{ }^{39}$ The dating of the Contemporary to the 1960 s and 1970 s as of "early experimentations" $" 40$ or "developments",41 indicates a search for origins in historical narrative and an effort to create an organic bond with the previous period, as seen in the studies from the Early Republican Period that link art in Turkey with Asia. Contemporary has been characterized by how the artist Altan Gürman (1935-1976) made an 
“individual break” with Modernism, and how with the work of Sabri Berkel (1907-1993) a "transition into postmodernism" was achieved, ${ }^{42}$ or that the proliferation of conceptual art and installations in the 1980s "was encouraged by the fact of object painting" Gürman "brought forward in the 1960s with a radical questioning." These datings exemplify the search for origins for the Contemporary. $^{43}$

As a result of this search, the narratives expand in time and a historical continuity is created between artistic practices. This suggests that a progressive historical narrative is favored, which is further supported by the claims of the narratives that the Contemporary was premised by Poststructuralist theories. In this way, a transition between Postmodernism and Contemporary is created. Hence a continuous relation between the Modern, (Postmodern), and the Contemporary in the arts in Turkey is proposed. On the one hand, these narratives create a history that is unique to Turkey by presenting its own breaks and developments. On the other hand, they serve for the creation of a temporal and terminological synchronicity with Western art history.

\section{Current}

The word Current often appears in the art histories of Turkey since the 1990s, yet before it designated a period, it was used in the sense of current art scene or current art events since the 1970s, similar to the first uses of the Contemporary. ${ }^{44}$ This word, which is used to qualify the art of the day, creates a temporal awareness. One of the first uses of the word Current as a stylistic designation belongs to 1982. In this narrative, Current Art is defined as "a mode of expression that introduces concepts and principles directed at society, development, and future" and "Western Art," which manifests rapid change and transformation like all other phenomena, in a fashion that is peculiar to the end of the twentieth century," and as a "universal language." 45 Hence, Current began to describe a way of making art, apart from indicating a certain temporality.

Current, which is also one of the sub-periods for the Contemporary, is dated to the $1990 \mathrm{~s}^{46}$ This is because some narratives suggested that the art displayed at the Youth Action exhibitions of 
the 1990 s were the forerunners of Current. ${ }^{47}$ Yet, the beginning of the Current is situated in the 1960s, grounded on the works of Sarkis (b. 1938) and Altan Gürman. ${ }^{48}$ Considering the fact that the same dating is provided for the Contemporary as well and the same artists are incorporated into those narratives, then these two periods coincide with each other, or include one another. However, Current and Contemporary are distinguished from each other in their definitions. Contemporary is defined as a period during which a concept is introduced into art, that is related to the "image usage based on meaning and sign, ${ }^{, 49}$ or as related with the discourse of the Republican project, and as a concept that is interwoven with the Modern. ${ }^{50}$ Current is defined as artworks that mostly have a political and reactive expression "that can touch its own time, and make the issues of its time visible as a field of representation;" that are "outside the modernization project which is itself a part of an ideological project;" and, that is "something made by everyone for everyone, ... something embracing everyday life, ... openly confronting the society and its norms.",53

Even though it is claimed that Current is not formed by a group of artists "complete with a unifying political agenda, defending the same cause," 54 it is nevertheless described through artists. Descriptions that exemplify this are as follows: "a movement starting in the 1990s among certain artists,,$" 55$ and "an constellation of artists whose works have been shaped by a specific discursive interaction and affinity in the past two decades, and the relationship of this constellation with politics," ${ }^{56}$ and a grouping among which Hüseyin B. Alptekin (1957-2007), Halil Altındere (b.1971), Esra Ersen (b.1970), Gülsün Karamustafa (b.1946), Aydan Murtezaoğlu (b.1961), Serkan Özkaya (b.1971), Bülent Şangar (b.1965), and Vahit Tuna (b.1971) are among the first artists to be mentioned. ${ }^{57}$ On the other hand, describing Current through artists such as Cengiz Tekin (b.1977), Erkan Özgen (b.1971), and Berat Işık (b.1976) as artists from Diyarbakır, ${ }^{58}$ who "turned [the city] into something of a focal centre for art that had previously been on the periphery" under the 
designation of "artists from south-east Turkey",59 or "Anatolian tigers," identities, such as Kurdish, that the Current comprises.

The designations defined through artists in other art histories during the same period, such as the Young British Artists (YBA) in Britain or the New Art in Iceland, have not turned into a name of a period as it happened with Current. ${ }^{61}$ Artists from south-east Turkey have stated that they identify themselves as the "generation $95 . " 62$ However, this name is not established in art historiography nor has become a period name. On the other hand, the Current has gone beyond solely covering a generation of artists; it has expanded by including artists such as Gürman and Sarkis. Hence, it has extended to the 1960 s and taken its place in the art history of Turkey as the name of a period.

In addition to referring to an entirety in relation to artists and artworks, Current also points to a temporal issue as a concept. Contemporary was treated in relation with the modernity project, in addition to approaching it in the sense of having the same temporal existence. However, alleged to begin right after the Contemporary or around the same time, Current signifies a temporality that is more recent with respect to now. With the use of the word Current in statements such that "a favorable environment for having access to current art events" could not be established in Turkey, or that Turkey can provide "artworks that do not fall short of the current artworks in the West but [are] at a level that can compete with them,",63 a conceptualization is structured, which would carry a step further the temporal parallelism that has supposedly been established through the Contemporary. Descriptions of the period of 1970-1980 in terms of "attempts at integrating with contemporary Western art," in contrast to the 1980s and 1990s described as a period when "a universal level has been achieved" $" 64$ and the "current art has reached the level of the global world;" 65 views stating that "the changes that took place in Europe during the 1990s happened here [in Turkey] around the same time period"66 all support the argument that the idea of temporal parallelism was promoted. In this sense, Current as a period closes the distance that is believed to 
exist with the artistic practice, which is now perceived globally, and creates a periodization that transforms the discourse of "inadequacy" that is often observed in art historiography in Turkey. Current [güncel] is, however, translated as contemporary in art-historical narratives that are published bilingually with an English translation. ${ }^{67}$ The word "çağdaş" is similarly translated into contemporary. ${ }^{68}$ Assuming that the English texts are intended for an Anglophone audience, the objective was to convey or present the arts in Turkey to this audience through these translations. Yet, the lack of a distinction between contemporary and current in these translations shows that the Current as a period name and as an art-historical term was only intended for readers in Turkey. It is clear that Current is a periodization that is unique to Turkey, unmatched in the general art history literature, and a period name solely created and problematized for art historiography in Turkey. Hence, it is possible to conceive the Current with Pierre Bourdieu's concept of “distinction." Elçin Gen uses this concept in opposition to Current. ${ }^{69}$ However, it is precisely as in distinction that Current creates "both a distinction that simply points at a difference, and a symbolic distinction that is based on this difference." In this sense, Current both creates a distinction in terms of art practices by way of its definitions, and grounds itself on this difference and hence distinguishes itself from the Modern and Contemporary.

In relation to the concept of modernity, Keith Moxey states that time unfolds at unequal speeds in different locations and this calls forth different contemporaneities. ${ }^{70}$ Yet Moxey also argues that these different contemporaneities are still specified and controlled by the dominant cultures of the global art world. It appears that the period called Current in art historiography in Turkey can counter this argument because Current is a result of a different contemporaneity that emerges only in Turkey. Current distinguishes itself from Contemporary and comes to exist as a period that is peculiar to art history in Turkey. Considering the fact that Kurdish artists, who produce politicized works critiquing nationalism, have gained importance within the constellation of artists that the Current seems to cover, it is significant that the Current highlights the Other, 
which Turkish nationalist ideology has created against the master art history. With this aspect, Current also provides an alternative to the periodization that modern art history makes under the name Contemporary.

Modern Art, Contemporary Art, and Current Art are distinguished in art historiography in Turkey as terms that express certain ways of making art. In art historical scholarship, too, these terms are used both to signify a period and as words that describe a certain way of making art. ${ }^{71}$ Especially in English and German narratives, the initials of the terms such as Zeitgenössische Kunst or Modern Art are always written in upper case in order to underline this distinction and different aesthetic ideals. ${ }^{72}$ In the art historical narratives in Turkey, however, the initials of modern art, ${ }^{73}$ contemporary $\operatorname{art}^{74}$ and current $\operatorname{art}^{75}$ are mostly written in lower case. But then in some narratives dealing with the history of the Current Art, we find Current Art written in both upper case and lower case. ${ }^{76}$ It is clear that the purpose of this usage is to distinguish Current as a concept that signifies a certain style, as in German and English, and hence to highlight its distinction.

Having said this, the general tendency in these narratives is to make a temporal distinction between Modern Art, Contemporary Art, and Current Art as well. Since this periodization and conceptualization has followed the principles of modern art historiography, differing views on approaching these terms have emerged. It is claimed, for instance, that what is precisely understood by the Modern and modernity is not clear in the art-historical debates in Turkey. ${ }^{77}$ However, there is indecisiveness on this issue in scholarship as well. Since modern art historiography has been taken as the reference for the periodizations in Turkey, the process of translating these terms into Turkish has often caused a terminological confusion. Yet, as seen in the case of the Current, these translations have also led to the emergence of temporalities for art history in Turkey that are different from those in modern art history.

On the other hand, also other large periods are found in art historiography in Turkey after 1970, other than Modern, Contemporary, and Current. With names such as Republican Period or 
Period of Galleries in the narratives written by art historians Semra Germaner, Ahmet Kamil Gören, and Sezer Tansuğ, these periods encompass artistic practices and artists without specifying certain ways of art-making or certain standards. Yet the idea of progress, linear history and chronology are also prevailing in these narratives.

Along with Modern, Contemporary, and Current, there are also small periods that focus on shorter temporal intervals within art-historical narratives in Turkey written between 1970 and 2010. As in the large periods of Modern, Contemporary, and Current, the smaller periods also focus both on the ways of art-making and on time. The smaller periods are, however, much narrower in scope with respect to artistic tendencies than large periods. While large periods can cover more styles, small periods periodize artists and artistic practices in shorter temporal intervals. Modern art history has used and extended its authority and its power in institutionalizing knowledge through periodization and has universally categorized artistic practice. ${ }^{78}$ It is therefore possible that, in art historiography in Turkey, too, these small periods have generated a standard for all artistic practices that existed within the same time period and have left those that fall short of these standards out of these narratives.

\section{Small Periods: Groups, Styles, and Generations}

James Elkins states that the models for periodization that are chosen in art historiography are based on a problem that grounds the narratives. ${ }^{79}$ Ernst Gombrich's book The Story of Art (1950) is an example of the integration of diverse trajectories in history into a single story by way of addressing the emergence of realism in Western painting. In this respect, scholars have argued that the problem, which grounds periodizations that exist in art historical narratives in Turkey, is to create a temporal and stylistic parallelism between art practices in Turkey and Modern Art in the West. Ali Artun suggests that artistic practices in Turkey between 1900 and 1950 were evaluated according to the "universal aesthetic codes" of modern art historiography and were forced to "comply with same periods/styles and with same taxonomies. ${ }^{, 80}$ Burcu Pelvanoğlu states that the narratives were 
structured according to an understanding of the model based on the groups and movements of Western art history. ${ }^{81}$ However, my study shows that there are variations in periodization in historical narratives on the art between 1900 and 1950, which were published after 1970. It also demonstrates that narratives that make periodizations based on local aspects or phenomena or that deal with singular artists, have emerged especially in art-historical narratives focusing on post-1970 art practices.

Zeynep Yasa Yaman remarks that the periodization envisioned for the modern art of Turkey by Burhan Toprak (1906-1967) and followed by Nurullah Berk (1906-1982) has been largely accepted in art historiography. ${ }^{82}$ Ali Artun argues that the art historiography of the period $1900-$ 1950 is a schema that "depicts more a corporative structure than an artistic one" and represents professional tendencies, and that this schema passed on from one writer to the next. ${ }^{83}$ Artun states that this periodization has been materialized as: Ottoman Painters' Association-New Painting Association - Independent Painters' and Sculptors' Union [in short "The Independents"]—The D Group - The Newcomers Group. ${ }^{84}$ On the other hand, Burcu Pelvanoğlu remarks that the Independents went beyond forming an association based on their artistic practice, while the D Group opposed forming an association. The track of Association of Ottoman Painters-New Painting Association — The Independents - The D Group — The Newcomers Group in Artun's statement is preserved in other narratives as well. ${ }^{85}$ Although stating that there are no technical or formal differences between the Independents and the D Group, some narratives still provide a periodization of that time period only through these two groups. ${ }^{86}$ This attests to the dominance of the narrative form that offers a corporative schema in art historiography, as suggested by Artun. This situation has similarities with the recurring periods in the historiography of modern art, and reveals a conception of historiography that is established as an authority in Turkey by being transmitted from one narrative to the next. 
Nonetheless, art-historical narratives that are analyzed for this study, revealed that in post1970 art historiography in Turkey periodizations that cover not just groups but tendencies and generations also exist. For example, Soldier Painters, Impressionists, and the D Group are widely canonized in these narratives.. Some of the periodizations and temporal organizations that are found are as follows: Academism/Naturalism - Impressionism — the Independents/Constructivism— the D Group/Cubism; ${ }^{87}$ Soldier Painters — Graduates of Darüşşafaka College — Çallı Generation — the Independents - the D Group; ${ }^{88}$ [insert fig. 3 near here] Turkish Primitives - Classical PaintersÇallı Generation-Expressionists—Cubism; ${ }^{89}$ Osman Hamdi and his period-Association of Ottoman Painters - Intergeneration - 1914 Generation — Şişli Atelier — the Independents — the D Group $;^{90}$ Romanticism-Impressionism-Cubism. ${ }^{91}$ [Insert fig. 4 and 5 near here]

Even though some of these periodizations include artists' professional organizations, they also provide models that are shaped around artists and artistic approaches. Narratives that form the first period with Turkish Impressionists, the second period with the Independents and the D Group, and the third period with the Newcomers Group ${ }^{92}$ or that follow the track of Turkish PrimitivesSoldier Painters - Impressionists - Constructivism ${ }^{93}$ exemplify periodizations that are organized around artists and styles.

Approaching Turkish Impressionists or Cubism-Constructivism as a period aims at a periodization that proceeds from style or artistic practice. ${ }^{94}$ However, mentioning the Independents and the D Group within the context of Cubist, Abstract Art, and Constructivist tendencies demonstrates that not only professional organizations but the artistic framework is taken into account as well. On the other hand, the fact that these groups are cast within the context of European-based movements, such as Cubism, suggests the issue of synchronicity between the art history of Turkey and the Western art history. Artun states that periods in art-historical texts focusing on the post-1950 period are similarly handled under titles such as Abstract Art and figurative expressionism, which rather serve "universal categories."95 
Small periods have also been discussed through certain "isms," such as Academism or Impressionism, through generations of artists like the Çallı Generation, after İbrahim Çallı (18821960), or through artistic tendencies. The narratives based on styles rather than artists' organizations; those that examine groups, generations, and tendencies, or groups together with styles; and those that incorporate these into metanarratives without excluding other artistic practices, also exist. There are also histories that provide periodizations with definitions rather than with certain period names, such as: "Primitives of Turkish painting under the influence of the West;" "Osman Hamdi and his friends who generally created works in an academic approach;" "Turkish impressionist painters" who produced works "in parallel to the new artistic movements in the West." 96 There are also examples in which the artists' birth dates, along with tendencies, are taken into account in providing periodization, which attests to the diversity of narrative structures.

Semra Germaner's narratives are structured in terms of the phenomena that shape practices, as, for instance, the role of the Academy of Fine Arts in artistic production; the Revolution Exhibitions of the Revolution [Inkllap Sergileri] that was held on the occasion of the tenth anniversary of the proclamation of the Republic; Homeland Tours [Yurt Gezileri] organized in 1938-1943; and in terms of institutions such as state, academy, and exhibitions, along with cultural policies. Hence, they exemplify a reading of art's history in Turkey from a different perspective. In this approach, Germaner divides her historical narrative into two main periods of the Republican Period and Period of Galleries, for instance. She argues that social, political, and economic changes that took place after 1950 had an impact on wide mass culture and on plastic arts. ${ }^{97}$ This explains her choice for this narrative structure.

In her historical narrative that focuses on the relations between state, art, and the global art environment, Beral Madra similarly divides history into five stages based on these relations, and provides another example of unusual periodizations: art as a means of the state-directed Westernization project (1850-1923); as a means of promoting modernism, while being to a certain 
extent "an individual act" and progressive (1923-1970); as an "apparatus for the left ideologies" (1960s); as intellectual act (1970-1980); and as connected to global cultural industries and global systems (from 1990s to 2007). ${ }^{98}$ There are also other texts that periodize their art-historical narratives from the perspectives of economy, politics, or culture. ${ }^{99}$

The diversity in periodization approaches increases within the historical narratives focusing on artistic practice after 1970. Based less on groups or generations, these narratives are marked by periods shaped around artistic tendencies or explorations, materials, concepts, or styles. Examples of this approach are periodizations arranged under the titles of "innovative tendencies," "lyrical explorations in the synthesis of figure and abstract," "social (realist) tendencies"; ${ }^{100}$ or according to artists, who produce work with socialist, abstract, and expressionist tendencies; ${ }^{101}$ or periodizing artists, who produced work after 1980 under four tendencies: those who produced "works that do not demonstrate a change within a decade" and maintained a "prosaic expression"those who chose a "realistic figure tradition"- - those who pursued New Expressionism—and, those who "achieved significant steps" and "improvements" in three-dimensional work and the arrangement of space. $^{102}$

The stylistic diversity, which Kemal İskender stresses that emerged after 1970, is one of the reasons for making periodizations based on tendencies. ${ }^{103}$ Another reason is that it is difficult to create periods since these narratives are handling a very short period of time. That fewer artist groupings are observed after this date is another reason why tendencies became period designations. In addition to all these, since the 1970s art has been periodized under Contemporary or Current in narratives, creating sub-periods may be deemed unnecessary.

Historical narratives about art practices after 1970 have also defined periods through phenomena that occurred during the specified temporal intervals. These phenomena are related both to socio-economic and cultural conditions and to the transformations that are observed about the works. For example, it has been argued that between 1970 and 1980 "Turkish art made efforts to 
integrate with contemporary Western art," while the 1980s and the 1990s is "a period in which a universal level has been achieved." ${ }^{\prime 104}$ The years between 1968 and 1978 are conceived as a period when capital accumulation and an art market emerged and "the art movements and techniques of the twentieth century began to gain currency" with "developments," so that three-dimensional or conceptual works began to appear in exhibitions, while 1978-1988 is conceived as a period of international art events in which individualism was emphasized, media grew, and an inquisitive and selective approach emerged. ${ }^{105}$

Until the 1960s, the view that art prevailed over social and political conditions dominated narratives globally. From then on, art historiography leaned toward Marxism as art was seen as the product of social actors, who work within specific social conditions, and the historical production and consumption of meanings and values were emphasized. ${ }^{106}$ This is why the existence of narratives that take socio-economic factors as a reference point for periodizations in art historiography in Turkey after 1970 can be attributed to the changes in the wider discipline of art history. However, these narratives do not exemplify a social history of art, but an approach of using history as a background of art that T.J. Clark opposes. ${ }^{107}$ In this respect, institutional, socio-political, or economic art historical narratives were grounded on various phenomena and events. Among these are exhibitions, such as New Tendencies [Yeni Ĕgilimler] and A Cross Section of Avantgarde Turkish Art [Öncü Türk Sanatından Bir Kesit]; the increasing international dialog; the emergence of a curatorial profession; or the effects of political, economic, and social transformations that took place in Turkey. ${ }^{108}$

The narratives also include the periods of Çallı Generation, 1914 Generation, and 1968 Generation. Generations, which mark a period through an artist or a date, arise in art historiography as time frames that surpass each other. Donald Preziosi argues that Giorgio Vasari (1511-1574), who is regarded as the first modern art historian, reduced historical differences to a singular, progressive, linear narrative in his book Le Vite (1550). ${ }^{109}$ Vasari's narrative, based on the idea of 
progress, implies that every generation has a mission and each establishes a norm or a standard through which the similar practices of all successive generations will be assessed. Accordingly, each generation takes over the mission of pushing the precedent forward. An array of generations leads to the idealization of artists as the representatives of various artistic practices. This has led to the establishment of artists like İbrahim Çallı as a standard in the art histories of Turkey. Nevertheless, periodizations such as 1914 or Çallı Generation mark 1914 in a temporal sense. The lack of this mark for this date in the art-historical narratives of other regions and its only presence in art history in Turkey can be construed as a sign of originality or the attempt to create a Turkish version of "the myth of the artist as creative genius" of the Western art history.

Beside creating a generational narrative in his book, Vasari also composes a series of monographs by producing artist biographies. This approach has led to the foundations of the subject-centered biographic tradition in art history, bringing the artists forward. Yet this narrative structure has created the myth of the artist as a hero or artistic genius. Turning each turned into a criterion, the artists were mythologized in the narratives as the focus shifted to individual artists.. This narrative structure also made it easier to create a canon based on artists. An example of this type of narrative from the histories of Turkish art is the sub-periodization made by Erden Kosova under the Current as First Generation Artists (Altan Gürman, Füsun Onur, Sarkis, Ayşe Erkmen, Serhat Kiraz, Yusuf Taktak, Canan Beykal, Gülsün Karamustafa, Cengiz Çekil, Hale Tenger, Selim Birsel, Aydan Murtezaoğlu, Bülent Şangar) and Second Generation Artists (Esra Ersen, Serkan Özkaya, Vahit Tuna, Halil Altındere). ${ }^{110}$ On the other hand, the same author also proposed to approach art after 1960 through an array or a constellation of artists, instead of generations. ${ }^{111}$ Constellations are important for offering both a reading and a periodization based on interactions among artists while dissolving the hierarchy between generations. This type of periodization allows for the creation of a meta-generational structure by moving away from the dominant form of generational narrative, and at the same time for the distancing from the idea of progress. ${ }^{112}$ Histories 
that embrace this structure are more often found in narratives on Contemporary or Current art in Turkey and in the global Contemporary Art historiography. This may be explained by stylistic variations, which are claimed to emerge in art after 1970, or the reappearance of subject-centered histories that were boosted by "individuality processes," according to Akay. ${ }^{113}$ In this way, narratives on Contemporary or Current art in Turkey are establishing a connection with global Contemporary art historiography by creating myths of heroic artists.

\section{Conclusion}

The common point among historical narratives written through groups, styles, tendencies, or generations, but excluding those based on artist constellations (examined in the last section of this article), is their adoption of a progressive historiography. These narratives draw on the chronological and linear approach to history, which has formed the foundation of Western art history, and hence are founded on an idea of progress. Artun argues that the periodization of 19001950 shaped around artists' associations, instead of a narrative based on artists or styles as in Western art history, cannot be taken as an expression of autonomy. Yet, these narratives also take into account generations and styles along with artists' associations and provide an institutional reading of art's history. Nevertheless, the fact that these periodizations were transmitted from one narrative to another, even though with nuances, demonstrates a narrative tradition that is specific to art historiography in Turkey. On the other hand, this also shows the established positions of canon and of periodization, which suggests the dominance of these narrative structures in art historiography in Turkey. Yet, the heterogeneity in periodizing post-1970 art indicate that this established authority is slowly losing its impact.

Periodizing the history of art nonetheless promotes the progressive narrative model of history. In this way, the history of art is classified into large periods (Modern, Contemporary, Current) or into small periods (generations, artist groups), and a narrative of development is formed. As with the modern art historiography, periods perform the thinking on behalf of the reader and 
categorize art. Different artistic practices take their place in historical narratives as long as they fit the way of art-making within their period, or, often remain in the background if they do not. As a method that contributes to the progress of historical time on a chronological and linear course, periodization also recreates the chronology of modern art historiography for the arts in Turkey. However, narratives that depart from the chronology and linearity of periodization by diverging from this model and which challenge the understanding of progress, emerge as well.

After 1970 two large periods of Contemporary and Current have been added to the periodization of Modern, which was the basis among large periods observed in art historiography before 1970 in Turkey. These periods are distinguished from each other conceptually and temporally within art-historical narratives, yet they compose a historical continuity within artistic practices, repeating the biological narrative structure of modern art history. Accordingly, the use of Current generates a conceptualization that would carry forward the temporal synchronicity between Western Europe- North America and Turkey that was assumed to have been established through the means of Contemporary. Yet, expanding historically and temporally in its search for origins, the Current brings originality to art history as both a name of a period and as a conceptualization that emerges only in Turkey.

\section{Endnotes:}

* This article is a section of the author's PhD dissertation, which she defended in 2015 in the Art History Department at the Istanbul Technical University.

1. William A. Green, "Periodizing World History," History and Theory, 34, 2 (1995): 99.

2. Fredric Jameson, The Political Unconscious: Narrative as a Socially Symbolic Act (Ithaca: Cornell University Press, 1981), 28.

3. Green, "Periodizing World History," 101. 
4. Leonard Orr, "Modernism and the Issue of Periodization," CLCWeb: Comparative Literature and Culture, 7, 1 (2005).

5. James Elkins, Stories of Art (New York: Routledge, 2002).

6. David Perkins, "The Construction of 'the Romantic Movement' as a Literary Classification," Nineteenth-Century Literature, 45, 2 (1990): 130.

7. Wen C. Fong, "Why Chinese Painting is History," Art Bulletin, 85, 2 (2003).

8. Cao Yiqiang, "World Art Studies and the Historiography of Chinese Art" in Kitty Zijlmans and Wilfried van Damme (eds.), World Art Studies: Exploring Concepts and Approaches (Amsterdam: Valiz, 2008).

9. Kitty Zijlmans, "The Discourse on Contemporary Art and the Globalization of the Art System," in Zijlmans and van Damme (eds.), World Art Studies, 139.

10. Çağlar Keyder, "Whither the Project of Modernity? Turkey in the 1990s," in Sibel Bozdoğan and Reşat Kasaba (eds.), Rethinking the Project of Modernity in Turkey (Seattle: University of Washington Press, 1997), 37.

11. Ali Akay, “Threads of Progress Adhering to Modern Art in Turkey,” Third Text 22, 1 (2008), 99, Nusret Polat (trans.).

12. Levent Çalıkoğlu, "Osmanlı ve Cumhuriyet Türkiyesi'nde Modernleşme ve Modernizm," in Yeni Yapttlar Yeni Ufuklar (Istanbul: Istanbul Museum of Modern Art, 2009), 54.

13. Levent Çalıkoğlu, "Discovering the Identity, A Desire to be Contemporary," in Modern Turk: Turkish Art in the Second Half of the 20th Century (Istanbul: Istanbul Art Museum Foundation, 2001), 24-33, Zeynep Perker (trans.).

14. Levent Çalıkoğlu, “Geleneksel İrade ile Modernizm Arasında: 1950-1970,” in Modern Turk II (Istanbul: Istanbul Art Museum Foundation, 2007). 
15. Semra Germaner, "Modernisation of Turkish Art: 1950-1990," in Fulya Erdemci, Semra Germaner, and Orhan Koçak, Modern and Beyond: 1950-2000 (Istanbul: Istanbul Bilgi University Press, 2008), Nazım Dikbaş (trans.); Orhan Koçak, Modern ve Ötesi, Elli Yılın Sanatına Kenar Notları (Istanbul: İstanbul Bilgi University Press, 2008).

16. Ali Artun, “Hakkı Anlı ve Bir Yerel Modernizm Zamanı,” Sanat Dünyamız, 102 (2007): 65; Fulya Erdemci, "Breaking the Spell, Re-routing," in Modern and Beyond: 1950-2000 (Istanbul: Istanbul Bilgi University Press, 2008), Liz Amado (trans.), 256.

17. Elkins, Stories of Art, 16.

18. Marilyn Stokstad, Marion Spears Grayson, and Stephen Addiss, Art History (New York: Harry N. Abrams Inc, 1995).

19. Fred S. Kleiner and Christin J. Mamiya, Gardner's Art Through the Ages (Belmont, CA: Thomson/Wadsworth, 2004).

20. H.H. Arnason and Peter Kalb, History of Modern Art (Upper Saddle River, NJ: Prentice Hall, 2003).

21. Arthur C. Danto, After the End of Art (Princeton: Princeton University Press; 1997), 145.

22. Fredric Jameson, The Cultural Turn (New York: Verso, 1998), 8-27.

23. Danto, After the End of Art.

24. Hans Belting and Andrea Buddensieg, "From Art World to Art World," in Hans Belting, Andrea Buddensieg, and Peter Weibel (eds.), The Global Contemporary and the Rise of the New Art Worlds (Cambridge: MIT Press, 2013), 28.

25. Alexander Alberro, "Periodising Contemporary Art," in Zoya Kocur and Simon Leung (eds.), Theory in Contemporary Art Since 1985 (Malden, MA: Blackwell, 2005).

26. Beral Madra, Bir Bilanço (Istanbul: Karşı Sanat Çalışmaları, 2005), 21.

27. Beral Madra, “The Hot Spot of Global Art”, Third Text 22, 1 (2008), 105. 
28. Çalıkoğlu, "Discovering the Identity," 28; Erdemci, "Breaking the Spell," 260-261.

29. Akay, “Threads of Progress Adhering to Modern Art in Turkey”, 100.

30. Levent Çalıkoğlu (ed.), “Ali Akay” Çağdaş Sanat Konuşmaları 3 (Istanbul: Yapı Kredi Publications, 2008), 25-26; Ali Akay, “1990’lardan İtibaren Güncel Sanat,” in Birleşmeyen Sentez (Istanbul: Yapı Kredi Publications, 2010), 72.

31. Michel Foucault, The Archaeology of Knowledge (London: Routledge, 2002), 4.

32. Çalıkoğlu, “Ali Akay”; Levent Çalıkoğlu, “90’lı Yıllarda Çağdaş Sanat: Kırılma-GerilimÇoğulculuk,” in Çağdaş Sanat Konuşmaları 3 (Istanbul: Yapı Kredi Publications, 2008); Erdemci, "Breaking the Spell."

33. Wendy M.K. Shaw, Ottoman Painting: Reflections of Western Art from the Ottoman Empire to the Turkish Republic (London and New York: I.B. Tauris, 2011), 173.

34. Vasıf Kortun, “Gaspedilen Tarifler,” Resmi Görüş, February 19, 2014, accessed on December 18, 2017, http://resmigorus.blogspot.co.uk/2014/02/gaspedilen-tarifler.html.

35. Semra Germaner, "Cumhuriyet Döneminde Resim Sanat1," in Ayla Ödekan (ed.), Cumhuriyet'in Renkleri, Biçimleri (Istanbul: Tarih Vakfi Publications, 1999).

36. Beral Madra, “80’li Y1llarda Çağdaş Sanat,” Hürriyet Gösteri, 100 (1989); idem, “Çağdaş Sanatta İpuçlarını Yakaladık," Hürriyet Gösteri, 110 (1990); Erdemci, "Breaking the Spell”; Kortun, "Gaspedilen Tarifler."

37. Aykut Köksal, “Türkiye'de Çağdaş Sanat,” in Ayla Ödekan (ed.), Cumhuriyet'in Renkleri, Biçimleri (Istanbul: Tarih Vakfi Publications, 1999), 169.

38. Madra, "Çağdaş Sanatta İpuçları"; Erdemci, "Breaking the Spell."

39. Çalıkoğlu, “Ali Akay”; Çalıkoğlu, "90’lı Yıllarda Çağdaş Sanat.”

40. Erdemci, "Breaking the Spell.”, 263.

41. Madra, "Çağdaş Sanatta İpuçları," 48. 
42. Beral Madra, “Modern'den Postmodern'e -2-," Sanat Çevresi, 126 (1991), 48.

43. Ibid., 48; idem, Bir Bilanço, 22.

44. Kaya Özsezgin, “İlginç bir toplam,” Milliyet Sanat, 236 (1977), 27.

45. Beral Madra, “Güncel Sanat Üstüne Gözlem ve Yorumlar,” Sanat Çevresi, 39 (1982), 24. In an interview with the Vizon magazine in 2004, the curator Vasif Kortun remarked that he introduced the concept "Current Art" to Turkey a decade earlier. Yet, in the art historical narratives that were examined within the scope of this article, such a usage that supports this statement was not found.

46. Erden Kosova, "Yavaş Kurşun,” in Azra Tüzünoğlu (ed.), Dersimiz Güncel Sanat (Istanbul: Outlet, 2008), 19; Şener Özmen, "Mama, li turchi," in I Am Too Sad to Kill You! (Istanbul: artist, 2003).

47. Ali Akay, “Tophane'den geliyoruz...," in Azra Tüzünoğlu (ed.), Outlet Almanak 2008-2009 (Istanbul: Outlet, 2009), 8.

48. Halil Altındere and Süreyyya Evren, “Preface: Who Reads a User's Manual Anyway?” in Halil Altındere and Süreyyya Evren (eds.), User's Manual: Contemporary Art in Turkey, 1986-2006 (Frankfurt and Istanbul: Revolver Archiv für aktuelle Kunst and art-ist,2007), 2.

49. Müjde Yazıc1, “Sanat Çağdaş mı, Güncel mi?” Radikal, October 21, 2007, accessed on December 18, 2017, http:/www.radikal.com.tr/kultur/sanat-cagdas-mi-guncel-mi-829239/.

50. Vasıf Kortun, “Gaspedilen Tarifler,” Resmi Görüş, published in February 19, 2014, accessed on December 21, 2017, http://resmigorus.blogspot.co.uk/2014/02/gaspedilen-tarifler.html

51. Yazıcı, "Sanat Çağdaş mı, Güncel mi?"

52. Kortun, "Gaspedilen Tarifler."

53. Burak Delier, "2000s: A Time for Departure for Contemporary Art," in Be a Realist, Demand the Impossible! (Istanbul: art-ist, 2007), 56, Yiğit Adam (trans.). 
54. Ibid., 56.

55. Ayşegül Sönmez, "Current Art in Turkey 2000-2007, Determinations and Incidents,” in Halil Altındere and Süreyyya Evren (eds.), User's Manual: Contemporary Art in Turkey, 1986-2006 (Frankfurt and Istanbul: Revolver Archiv für aktuelle Kunst and art-ist, 2007), 136.

56. Kosova, "Yavaş Kurşun," 19.

57. Özmen, "Mama Li Turchi."

58. Şener Özmen (2008) “Art on the Line...," Third Text, 22:1, 113, translated by Liz E. Amado,

59. Akay, "Threads of Progress Adhering to Modern Art in Turkey", 97.

60. Akay, “Tophane'den geliyoruz...," 8.

61. Æsa Sigurjónsdóttir, “New Maps for Networks: Reykjavík Fluxus - A Case of Expanding Connections," in Martha Langford (eds.), Narratives Unfolding: National Art Histories in an Unfinished World (Montreal \& Kingston: McGill-Queen's University Press), 191.

62. Akay, "Threads of Progress Adhering to Modern Art in Turkey," 101.

63. Madra, “Güncel Sanat Üstüne,” 26.

64. Germaner, "Cumhuriyet Döneminde," 22.

65. Burcu Pelvanoğlu, "Darbe(ler) Sonrasında Sanat ve Sanatç1," in Ahmet İnsel et al., Darbe (Istanbul: Outlet, 2009), 54.

66. Çalıkoğlu, “Ali Akay,” 25.

67. Kamil Şenol, "Contemporary Art in Istanbul," in Be a Realist, Demand the Impossible! (Istanbul: art-ist, 2007), Yiğit Adam (trans.); Özmen, “Art on the Line...”: Beral Madra, $A$ Conceptual Heritage, Vanguard Installations, (Istanbul: Antik A.Ş., 2011), Nazım Hikmet Dikbaş (trans.).

An exception in this respect is the subtitle of the "İskorpit" exhibition that was organized in Berlin in 1998: the subtitle was published as "Recent Art From Istanbul” in English. 
68. Vasif Kortun argues that "contemporary" has been improperly translated into Turkish as “çağdaş,” but actually stands for "güncel," while "modern” should be translated as "asri”"; see, Mehmet Refik, “Küratörlük Araştırmaları Merkezi,” Arredamento Dekorasyon, 69 (1995).

69. Elçin Gen, "Çağdaştan Güncele, Eserden İşe: Bir Çeviri Hikayesi,” E-Skop, August 7, 2012 accessed on December 18, 2017, http//www.e-skop.com/skopbulten/cagdastan-guncele-eserdenise-bir-ceviri-hikayesi/847/.

70. Keith Moxey, Visual Time: The Image in History (Durham: Duke University Press, 2013 ), 17.

71. Alberro, "Periodising Contemporary Art."

72. Maureen Butler and Phil Freshman (eds.), Association of Art Editors Style Guide, Revised Edition 2013, accessed on March 4, 2015 //www. artedit.org/styleguide.htm-artmove/.

I would like to thank Prof. Dr. Wendy M.K. Shaw for her contribution to this work in relation to this topic.

73. Jale N. Erzen, "Yeni Eğilimler - Genel Bir Değerlendirme," Yeni Boyut Plastik Sanatlar Dergisi, 18 (1983); Erdemci, "Breaking the Spell;” Germaner, "Modernisation of Turkish Art”; Koçak, “50 Years of Modern Art,” Modern and Beyond: 1950-2000, Victoria Holbrook (trans.)

74. Köksal, “Türkiye’de Çağdaş Sanat”; Madra, “80’li Yıllarda;” Beral Madra, "Visual Art as a Field of Complication," in Halil Altındere and Süreyyya Evren (eds.), User's Manual: Contemporary Art in Turkey, 1986-2006 (Frankfurt and Istanbul: Revolver Archiv für aktuelle Kunst and art-ist, 2007); Erdemci, “Breaking the Spell”; Ezgi Bakçay, “1980-2000’e Güncel Sanat," in Ahmet İnsel et al., Darbe (Istanbul: Outlet, 2009).

75. Kosova, "Yavaş Kurşun”; Bakçay, "Güncel Sanat.”

76. Halil Altındere, "Introduction: Contemporary Art in 1986-2006" in Halil Altındere and Süreyyya Evren (eds.), User's Manual: Contemporary Art in Turkey, 1986-2006 (Frankfurt and Istanbul: Revolver Archiv für aktuelle Kunst and art-ist, 2007). 
77. Koçak, "50 Years of Modern Art,” 22.

78. Susan Stanford Friedman, "Definitional Excursions: The Meanings of

Modern/Modernity/Modernism,” Modernism/Modernity, 8, 3 (2001): 506.

79. Elkins, Stories of Art, 58.

80. Ali Artun, “Çağdaş Sanat Tarihleri ve Türkiye'de Sanatın Çağdaşlaşması,” Toplum ve Bilim, 79 (1998): 61.

81. Burcu Pelvanoğlu, Hale Asaf - Türk Resminde Bir Dönüm Noktası (Istanbul: Yapı Kredi Publications, 2007), 15.

82. Zeynep Yasa Yaman, "Beyond the Apparent: Visit to a Collection," in A Selection from the Art Collection of the Central Bank of the Republic of Turkey (Istanbul: Pera Museum Publications, 2011), 94-95.

83. Artun, "Çağdaş Sanat Tarihleri."

84. Ibid., 49-55. Artun's study is based on periodizations that existed in books among which he enumerates: Nurullah Berk and Hüseyin Gezer, 50 Yılın Türk Resim ve Heykeli [Turkish Painting and Sculpture of 50 Years], 1973; Adnan Turani, Batı Anlayışına Dönük Türk Resim Sanatı [Turkish Painting That is Turned Towards Western Understanding], 1984; Kaya Özsezgin, Mimar Sinan Üniversitesi İstanbul Resim ve Heykel Müzesi Koleksiyonu [The Collection of the Istanbul Painting and Sculpture Museum of Mimar Sinan University], 1996; Sezer Tansuğ, Çă̆daş Türk Sanatı [Contemporary Turkish Art], 1991.

85. Burcu Pelvanoğlu, "The Milestone on Turkish Art of Painting: The Academy Department of Painting," in Tutor Artists, Artist Tutors: (Istanbul: Türkiye İş Bankası Kültür Yayınları, 2010), 20-46, Ayperi Okur (trans.).

86. Kemal İskender, “Türk Resminin Dünü, Bugünü ve Geleceği,” Gergedan, 19 (1988). 
87. İpek Aksüğür, "Türk Resminde Yeni Eğilimler ve Yeni Eğilimler Sergisi,” Milliyet Sanat, Yeni Dizi 83 (1983).

88. Ibid.

89. Yahşi Baraz, Çăğdaş Türk Resminde Özgün Üsluplar (Istanbul: Galeri Baraz, 1996).

90. Ahmet Kamil Gören, “Cumhuriyetin 75. Yılında Türk Resim Sanatı,” Antik \& Dekor, 8 (1998); idem, "Çağdaş Türk Resim-Heykel ve Seramik Sanatının Gelişimi," in Turkuvaz 2000 - Çă̆daş Türk Plastik Sanatları'ndan Bir Kesit (Istanbul: Bilim Sanat Galerisi, 2000).

91. Kiymet Giray, The Centennial Tale of Turkish Painting, (Istanbul: Rezan Has Museum, 2007); idem, The

Centennial Tale of Turkish Painting II (Istanbul: Rezan Has Museum, 2009).

92. Nurullah Berk, “Resim Kültürel Yaşantımıza Son Elli Y1l İçinde Girdi,” Milliyet Sanat, 51 (1973).

93. Mümtaz Sağlam, Central Bank of the Republic of Turkey Art Collection 1 (Ankara: Central Bank of the Republic of Turkey, 2004), Fred Stark (trans.).

94. In another narrative of Berk, "Contemporary Primitives" is periodized as a movement as "First Turkish artists," see Niyazi Berk, "Çağdaş Sanatımızın Temsilcileri 9: Nazmi Ziya Güran,” Sanat Dünyamız 15 (1979): 47. Situated at the beginning of an art historical narrative, these periods are separate from the "corporative structure" that Artun suggests.

95. Artun, "Çağdaş Sanat Tarihleri," 59.

96. Kaya Özsezgin, “Sonraki Kuşaklara Ortam Hazırlayan Namık İsmail...,” Milliyet Sanat, 149 (1975).

97. Germaner, "Cumhuriyet Döneminde," 21.

98. Madra, "Visual Art as a Field of Complication," 30.

99. Canan Çoker, “Resim Sanatımız ve Tekelci Sermaye,” Sanat Emeği, 25 (1980). 
Even though they lie beyond the scope of this article, other examples of different historicizing are the composing of art history in Turkey through educational institutions, market, exhibitions, periodicals and styles in the books Çăgdaş Türk Sanatı [Contemporary Turkish Art] by Sezer Tansuğ (Istanbul: Remzi Kitabevi, 1986) and Türk Resmi ve Eleştirisi: 1900-1950 [Turkish Painting and Its Criticism: 1900-1950] by İpek Duben (Istanbul: İstanbul Bilgi University Press, 2007).

100. İskender, "Türk Resminin Dünü.”

101. Madra, "80’li Yillarda."

102. Madra, "Çağdaş Sanatta," 49-50.

103. İskender, "Modernizm ve 1975 Sonras1," 25.

104. Germaner, "Cumhuriyet Döneminde," 22.

105. Madra, "80’li Y1llarda."

106. Steve Edwards, Art and Its Histories (New Haven: Yale University Press, 1999), 6.

107. T.J. Clark, "On the Social History of Art," in Francis Frascina and Charles Harrison (eds.), Modern Art and Modernism: A Critical Anthology (London: Harper \& Row, 1982), 250.

108. Çalıkoğlu, "1990’lı Yıllarda”; Madra, Bir Bilanço; Madra, "Visual Art as a Field of Complication."

109. Donald Preziosi, The Art of Art History (Oxford: Oxford University Press, 1998), 24.

110. Erden Kosova, “Türkiye'de Güncel Sanat,” in Halil Altındere and Süreyyya Evren (eds.), User's Manual: Contemporary Art in Turkey, 1986-2006 (Frankfurt and Istanbul: Revolver Archiv für aktuelle Kunst and art-ist, 2007).

111. Kosova, "Yavaş Kurşun."

112. For instance, in his narrative the art critic Kemal İskender argues that artists within the groups such as the D Group or the Independents demonstrate diverse stylistic aspects and this is 
why he provides short studies that are based on artists; see Kemal İskender, "Modernizm ve 1975 Sonrası Türk Sanat," Sanat Çevresi, 120 (1988): 32-35.

113. Akay, “1990'lardan itibaren,” 72. 